\title{
Correction to: "It felt like my son had died": Zero tolerance and the trauma of family separation
}

\author{
Óscar F. Gil-García · Francesca Bové ${ }^{1}$ Luz Velazquez ${ }^{1}$ Sarah Vener ${ }^{1}$. \\ Alexandra Miranda ${ }^{1}$
}

Published online: 8 June 2021

(c) Springer Nature Limited 2021

\section{Correction to: Latino Studies https://doi.org/10.1057/s41276-021-00314-7}

Unfortunately, the article has been published with an incorrect e-mail address.

The correct e-mail address is: Alexandra Miranda: amirand9@binghamton.edu

Publisher's Note Springer Nature remains neutral with regard to jurisdictional claims in published maps and institutional affiliations.

The original article can be found online at https://doi.org/10.1057/s41276-021-00314-7.

Óscar F. Gil-García

Ogil@binghamton.edu

Francesca Bové

Fbove1@binghamton.edu

Luz Velazquez

lvelazq2@binghamton.edu

Sarah Vener

svener1@binghamton.edu

Alexandra Miranda

amirand9@binghamton.edu

1 Binghamton University, State University of New York, USA 